\title{
EVIDENCE FOR REJECTION OF HOMOGRAFT CARDIAC VALVES IN INFANTS
}

Bijal Rajani, MB, BS

Roger B. Mee, MB, ChB, FRCS

Norman B. Ratliff, MD
Objective: Concern about the durability of small homograft cardiac valves has been expressed by surgeons, and evidence has been found that homograft valves evoke a recipient immune response. We reviewed our experience with homograft valves for evidence of rejection. Methods: A search of our files revealed 11 homograft cardiac valves removed at reoperation and one at autopsy. Six valves were from adults, five were from infants, and one was from a 13-year-old child. Immunohistochemical studies with antibodies against smooth muscle actin, CD20, CD43, CD34, and CD68 were performed on the homografts containing inflammatory infiltrates. These valves happened to be the valves from the five infants. These five valves were also stained with Gram and Gomori's methenamine silver stains. Results: The failed homografts from the adults and 13-year-old child showed leaflet calcification, fibrosis, and degeneration, but no inflammation. The valves from the infants all failed in less than 8 months. The valve leaflets were thickened, and the valve leaflets and aortic sleeves contained a hyperplastic intimal layer with numerous spindle cells positive for smooth muscle actin embedded in a glycosaminoglycan matrix. The homografts contained multiple foci of inflammation consisting of $\mathrm{T}$ lymphocytes (in all five infant valves) and $B$ lymphocytes (in three of the five infant valves). Special stains for organisms were negative. Conclusions: Rapid failure plus lymphocytic infiltration in valve leaflets and aortic sleeves is consistent with rejection. The hyperplastic intima is similar to coronary arteries in transplant-associated vascular disease. Our observations are consistent with other reports of rapid failure of homograft valves in this age group. (J Thorac Cardiovasc Surg 1998;115:111-7)
A ortic valve replacement with homograft valves was introduced in $1962 .^{1}$ Since then, homografts (allografts) have been used to treat both acquired and congenital heart diseases. The main advantages over mechanical valves are the good hemodynamic performance and a relative freedom from valvular thrombosis in the absence of anticoagulation therapy. Although much has been written on the longterm durability of aortic valve homografts, ${ }^{2-8}$ concerns have been expressed about the durability of homograft valves in younger pediatric patients. ${ }^{9,} 10$

From the Departments of Anatomic Pathology and Cardiothoracic Surgery, The Cleveland Clinic Foundation, Cleveland, Ohio.

Received for publication Oct. 1, 1996; revisions requested Nov. 19, 1996; revisions received Jan. 15, 1997; accepted for publication March 10, 1997.

Address for reprints: Norman B. Ratliff, MD, Department of Anatomic Pathology, L25, The Cleveland Clinic Foundation, 9500 Euclid Ave., Cleveland OH 44195.

Copyright (C) 1998 by Mosby, Inc.

$0022-5223 / 98 \$ 5.00+0 \quad \mathbf{1 2 / 1 / 8 2 9 1 7}$
Homograft valves are usually transplanted without matching donor and recipient for blood group or human leukocyte antigens (HLA). Theoretically, the lack of blood vessels in cardiac valves should protect them from rejection. However, homografts can induce specific immune responses in vivo and in vitro in both animals and human beings, ${ }^{11-18}$ and it seems likely that the early homograft failure in young children is associated with immunologic factors. This observation has led to suggestions that short-course immunosuppression therapy might improve the durability of homograft valves, even though the cause of the rapid failure of homografts in some children has not yet been determined. We reviewed our experience with homograft valves at The Cleveland Clinic Foundation for evidence of possible rejection.

\section{Materials and methods}

The files at The Cleveland Clinic Foundation were searched for all homografts that had been removed at operation or reported at autopsy. Multiple sections (rang- 


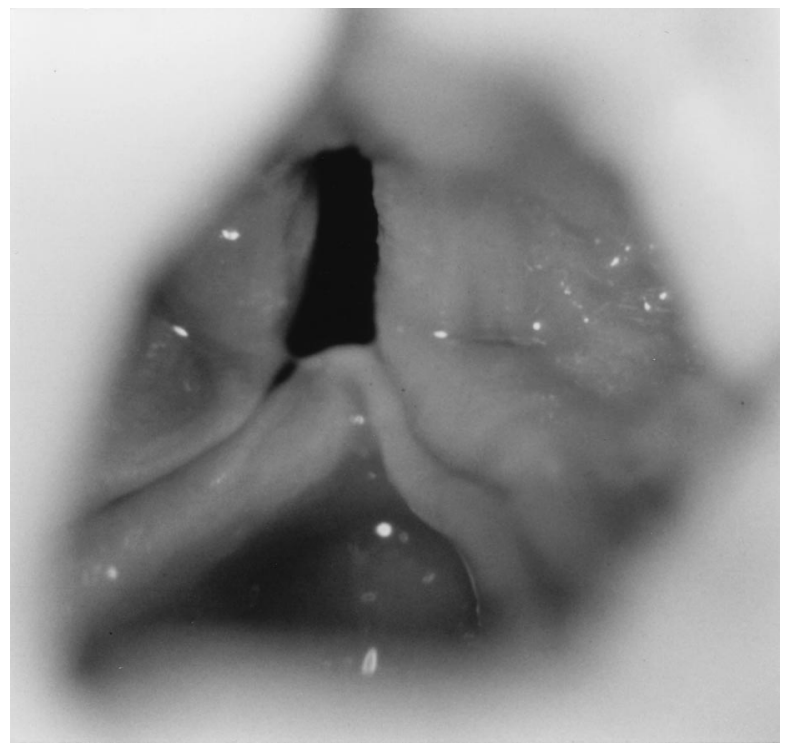

Fig. 1. Aortic valve in situ, from infant autopsy case, demonstrating thickening and retraction with failure of the valve leaflets to coapt.

ing from 3 to 25 , median 7) were taken from the explanted homograft valves and the homograft valve removed at autopsy. The tissue sections were fixed in $10 \%$ buffered formalin solution and embedded in paraffin. Sections 4 $\mu \mathrm{m}$ in size were obtained and stained with hematoxylin and eosin. After the sections stained with hematoxylin and eosin had been reviewed, further immunohistochemical studies were performed on all homografts containing an inflammatory infiltrate. With the use of an immunoperoxidase method, immunohistochemical evaluations with antibodies against smooth muscle actin, CD20 (for B lymphocytes), CD43 (for T lymphocytes), CD34, and CD68 (macrophages) were performed. ${ }^{19}$ In addition Gram, Gomori's methenamine silver, and Movat's pentachrome special stains were also used on these homografts with an inflammatory infiltrate to exclude infectious causes of inflammation and to clarify valve and aortic sleeve structure. When the gross, microscopic, and immunohistochemical findings in these cases were recorded, both the valve leaflets and the aortic sleeve were considered to be part of the graft because the aortic sleeves had been transplanted with the valve leaflet as part of the aortic homograft.

\section{Results}

Our search revealed 11 aortic homograft cardiac valves removed at reoperation and one at autopsy. Eleven of the valves were removed from the aortic position and one was from the pulmonary position. Six of the valves came from adults (ages ranging from 19 to 37 years at the time of valve insertion), one from a child of 13 years, and five from four infants (less than 1 year old at the time of valve insertion and explantation). One child had two aortic homografts removed at reoperation on separate occasions.

The 13-year-old child had the homograft valve inserted at an outside hospital when she was 6 years of age. It was replaced 7 years later for aortic insufficiency. Of the six adults, only one patient had the homograft inserted at The Cleveland Clinic. Available records for this patient reveal that the size of this homograft was $21 \mathrm{~mm}$ but the method of valve preservation and the sex and blood type of the valve donor are unknown. Similar information is also unavailable for the remaining five adults (as their homograft valves were inserted at various outside hospitals), except for one man whose homograft valve was known to have been cryopreserved. The length of graft survival for this patient was 6 years. The adult patients were all male, and lengths of graft survival ranged from 1.2 years to 23 years (median 6 years). The homografts were explanted because of aortic insufficiency in five of the six adults and suspected bacterial endocarditis in the other adult (no histologic evidence of suppurative inflammation).

Homografts from the 13-year-old child and the six adults showed similar histologic findings characterized by fibrosis, degeneration of leaflet collagen, calcification, and leaflet tears. Inflammation was not present. These changes are similar to those found in failed xenograft valves.

The five infant homograft valves were all implanted at The Cleveland Clinic Foundation and all five valves were cryopreserved. Information regarding valve sizes, sex and blood type of recipients and donors (the blood type of only two of the donors was known), age of infants at the time of valve insertion, length of graft survival, and available clinical information on indications for graft replacement is recorded in Table I.

The five homograft valves from the four infants contained a cellular infiltrate. Each of these valves had failed in less than 8 months and evidence of valve failure was noted 3 weeks after implantation at the earliest (patient 4) and 9 weeks at the latest (patients 2, 3, and 5). Four of the five valves were insufficient and the sleeve of the fifth homograft had become aneurysmal. Gross inspection of each explanted infant homograft valve revealed thickened valve leaflets. In the valve from the autopsy case, visualization of the homograft valve in situ revealed retracted valve leaflets that failed to coapt (Fig. 1). Microscopic examination of the valve leaflets and 


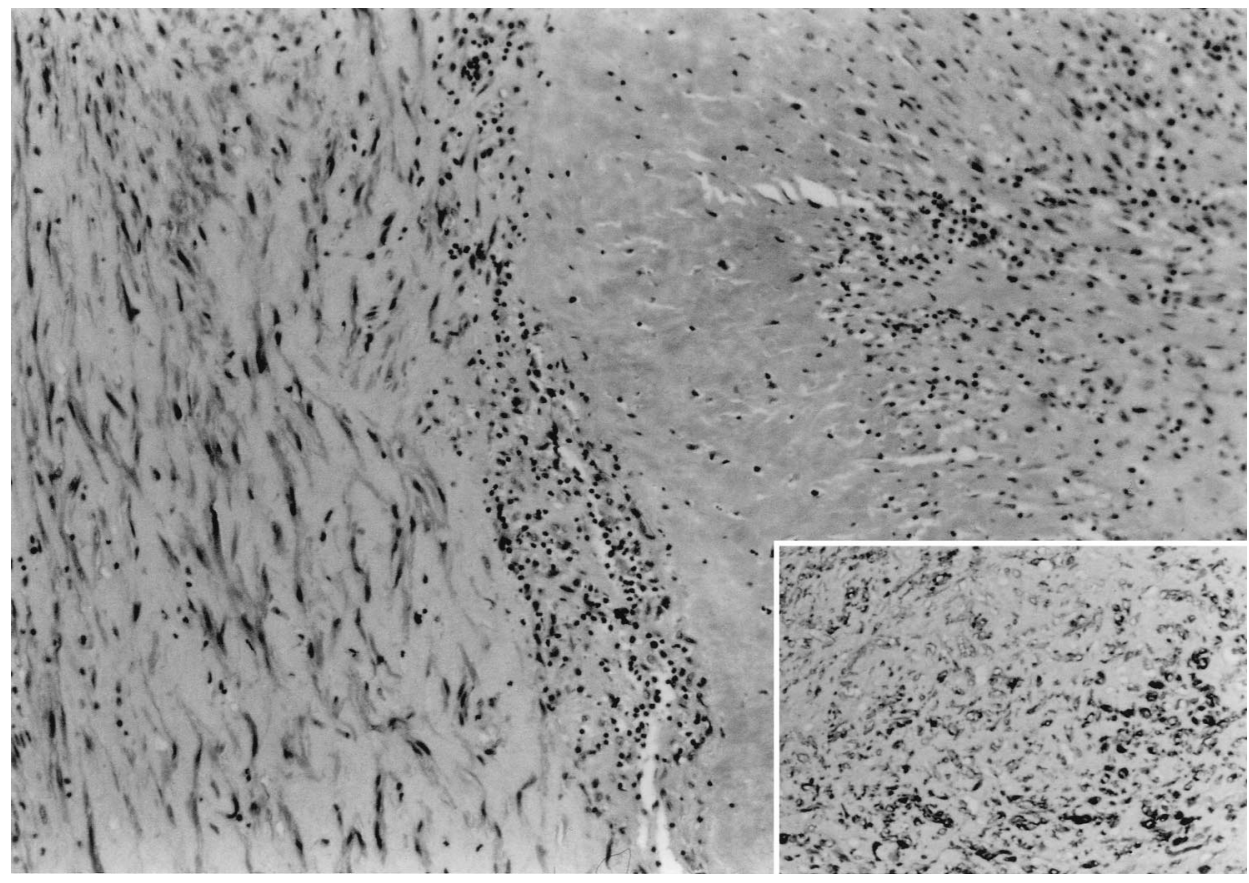

Fig. 2. Aortic sleeve from infant aortic homograft highlighting the spindle cell proliferation in the intima and the mononuclear inflammatory cell infiltrate present between the intima and media. (Hematoxylin and eosin; original magnification $\times 190$.) Inset: The spindle cells of the intima were identified as smooth muscle cells by demonstrating a positive staining pattern with antibodies against smooth muscle actin.

Table I. Clinical data on homografts from infants

\begin{tabular}{|c|c|c|c|c|c|c|c|c|c|c|}
\hline \multirow[b]{2}{*}{ Patient } & \multirow{2}{*}{$\begin{array}{l}\text { Valve } \\
\text { replaced }\end{array}$} & \multirow{2}{*}{$\begin{array}{c}\text { Valve size } \\
(\mathrm{mm})\end{array}$} & \multicolumn{2}{|c|}{ Sex } & \multicolumn{2}{|c|}{ Blood type } & \multirow{2}{*}{$\begin{array}{l}\text { Age at } \\
\text { insertion }\end{array}$} & \multirow{2}{*}{$\begin{array}{l}\text { Time of onset } \\
\text { of symptoms from } \\
\text { insertion (wk) }\end{array}$} & \multirow{2}{*}{$\begin{array}{l}\text { Indications for } \\
\text { graft replacement }\end{array}$} & \multirow{2}{*}{$\begin{array}{c}\text { Length of } \\
\text { graft survival (wk) }\end{array}$} \\
\hline & & & $R$ & $D$ & $R$ & $D$ & & & & \\
\hline 1 & AV & 9 & $\mathrm{~F}$ & M & $\mathrm{A}+$ & $\mathrm{U}$ & $21 / 2 \mathrm{wk}$ & 4 & $\begin{array}{l}\text { Severe AI presenting with } \\
\text { acute respiratory distress* }\end{array}$ & $61 / 2$ \\
\hline 2 & AV & 11 & M & M & $\mathrm{O}+$ & $\mathrm{O}-$ & $4 \mathrm{wk}$ & 9 & $\begin{array}{l}\text { Progressive AI leading to } \\
\text { severe cardiac failure }\end{array}$ & 15 \\
\hline $3 \dagger$ & $\mathrm{AV}$ & 9 & M & M & $\mathrm{O}+$ & $\mathrm{U}$ & 6 days & 9 & Significant AI & 18 \\
\hline $4 \dagger$ & $\mathrm{AV}$ & 11 & M & M & $\mathrm{O}+$ & $\mathrm{U}$ & $18 \mathrm{wk}$ & 3 & Progressive AI & 31 \\
\hline 5 & PV & 9 & $\mathrm{~F}$ & M & $\mathrm{A}+$ & $\mathrm{O}+$ & 1 day & 9 & $\begin{array}{l}\text { Developed aneurysm } \\
\text { of homograft }\end{array}$ & 13 \\
\hline
\end{tabular}

$A V$, Aortic valve; $P V$, pulmonary valve; $R$, recipient; $D$, donor; $F$, female; $M$, male; $U$, unknown; $A I$, aortic insufficiency.

*Patient died as a result of severe aortic insufficiency.

$\dagger$ Indicates the same patient.

aortic sleeves revealed a markedly thickened cellular intimal layer with numerous spindle cells embedded in a glycosaminoglycan matrix in all valves from the infants. These spindle cells were positive for smooth muscle actin (Fig. 2). Elastic tissue could be identified in the leaflets, but the normal layers of the valve beneath the hyperplastic intima were obscured by collagen. All five homografts from the infants contained multiple foci of inflammation, composed primarily of lymphocytes, in the valve leaflets (Fig.
3) and intima, media, and adventitia of the aortic sleeves (Fig. 4). The lymphocytes were present in aggregates of varying sizes in the aortic sleeves and as scattered individual cells in the valve leaflets. $T$ lymphocytes, identified by a positive staining reaction with CD43 (Fig. 5), were predominant in all five homografts, and B lymphocytes, identified by a positive staining reaction with $\mathrm{CD} 20$ (Fig. 6), were present in three of the five homografts. Macrophages were identified in only one valve. A few 


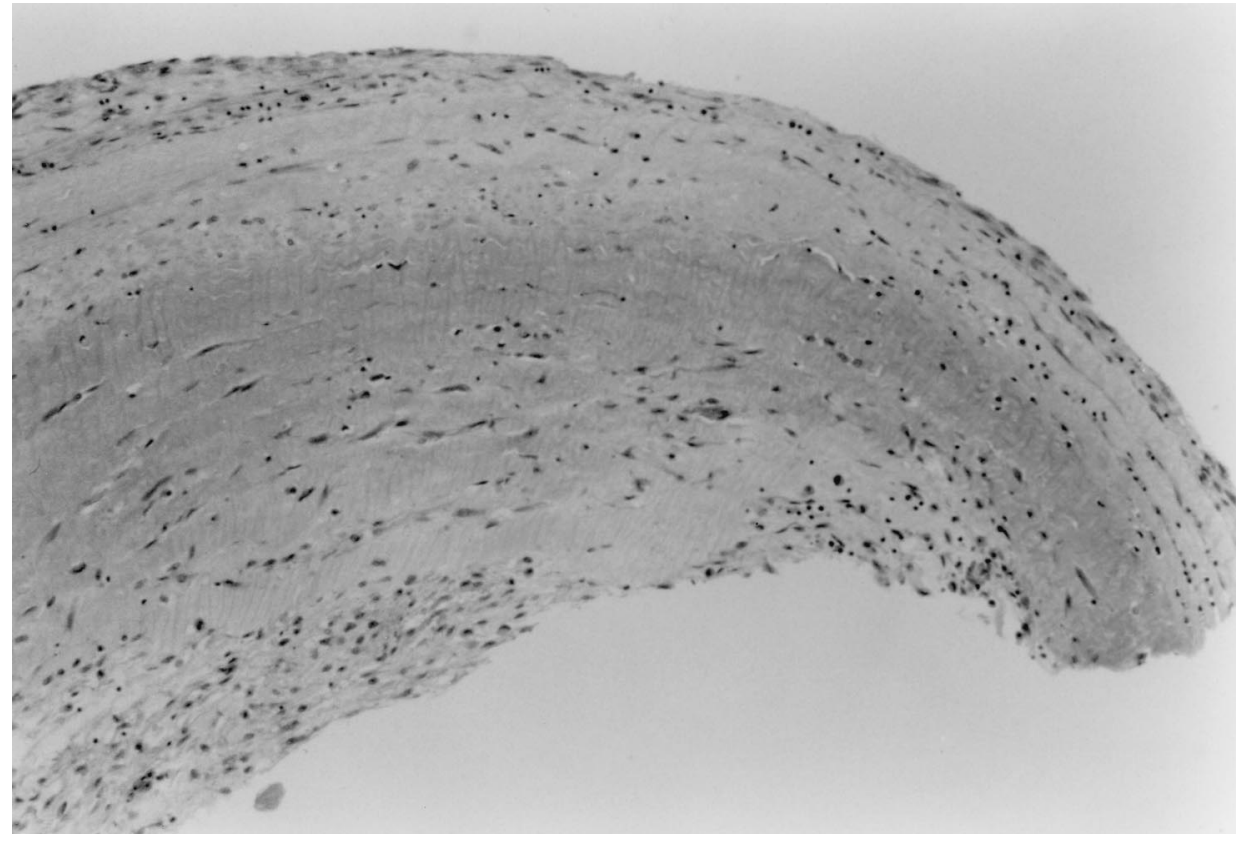

Fig. 3. Homograft valve leaflet highlighting the spindle cell proliferation on the surface of the valve and the mononuclear inflammatory cells infiltrating the valve leaflet. (Hematoxylin and eosin; original magnification $\times 230$ ).

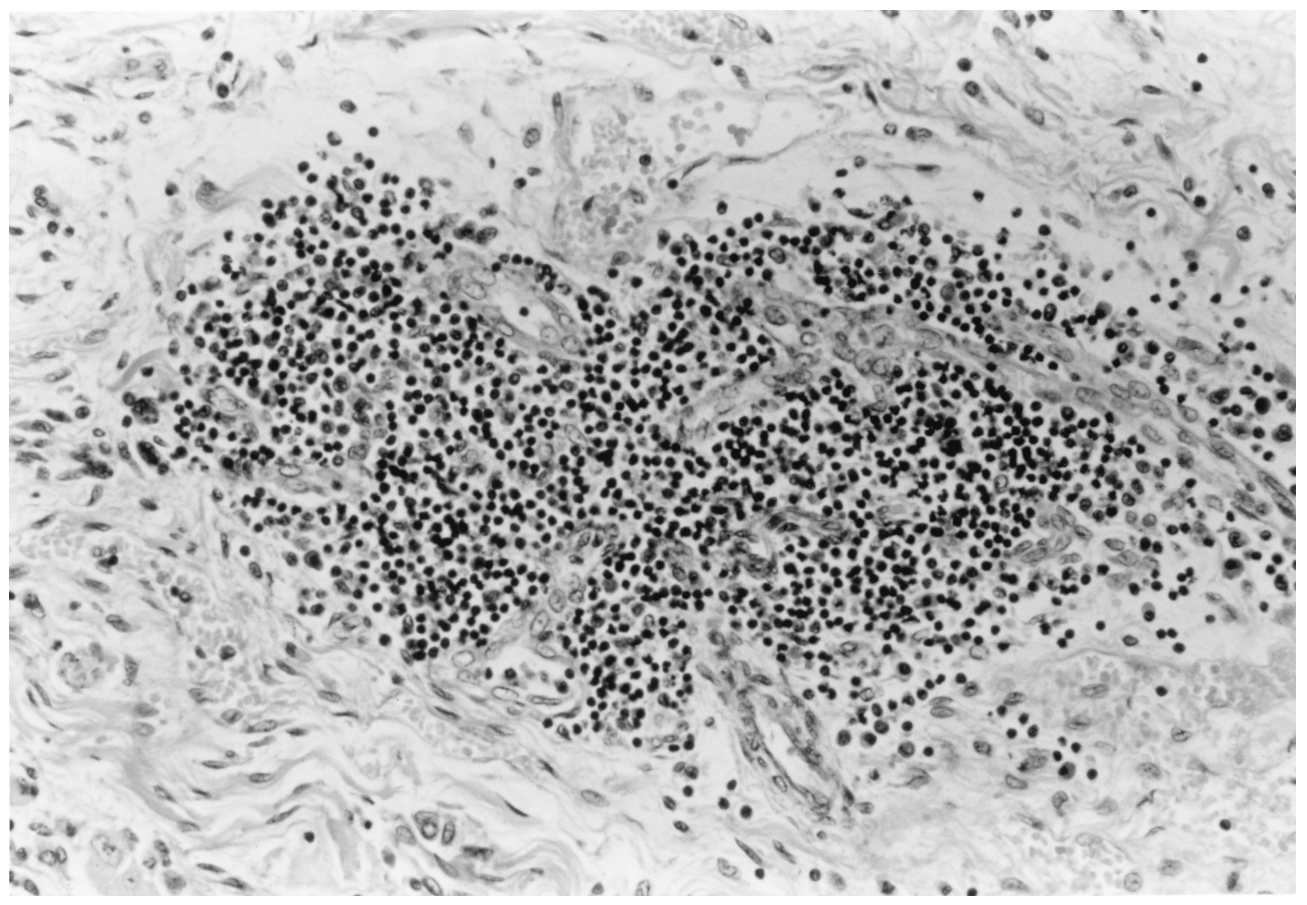

Fig. 4. An example of one of the multifocal mononuclear inflammatory cell infiltrates present in the aortic sleeve of an infant aortic homograft. (Hematoxylin and eosin; original magnification $\times 310$.) 


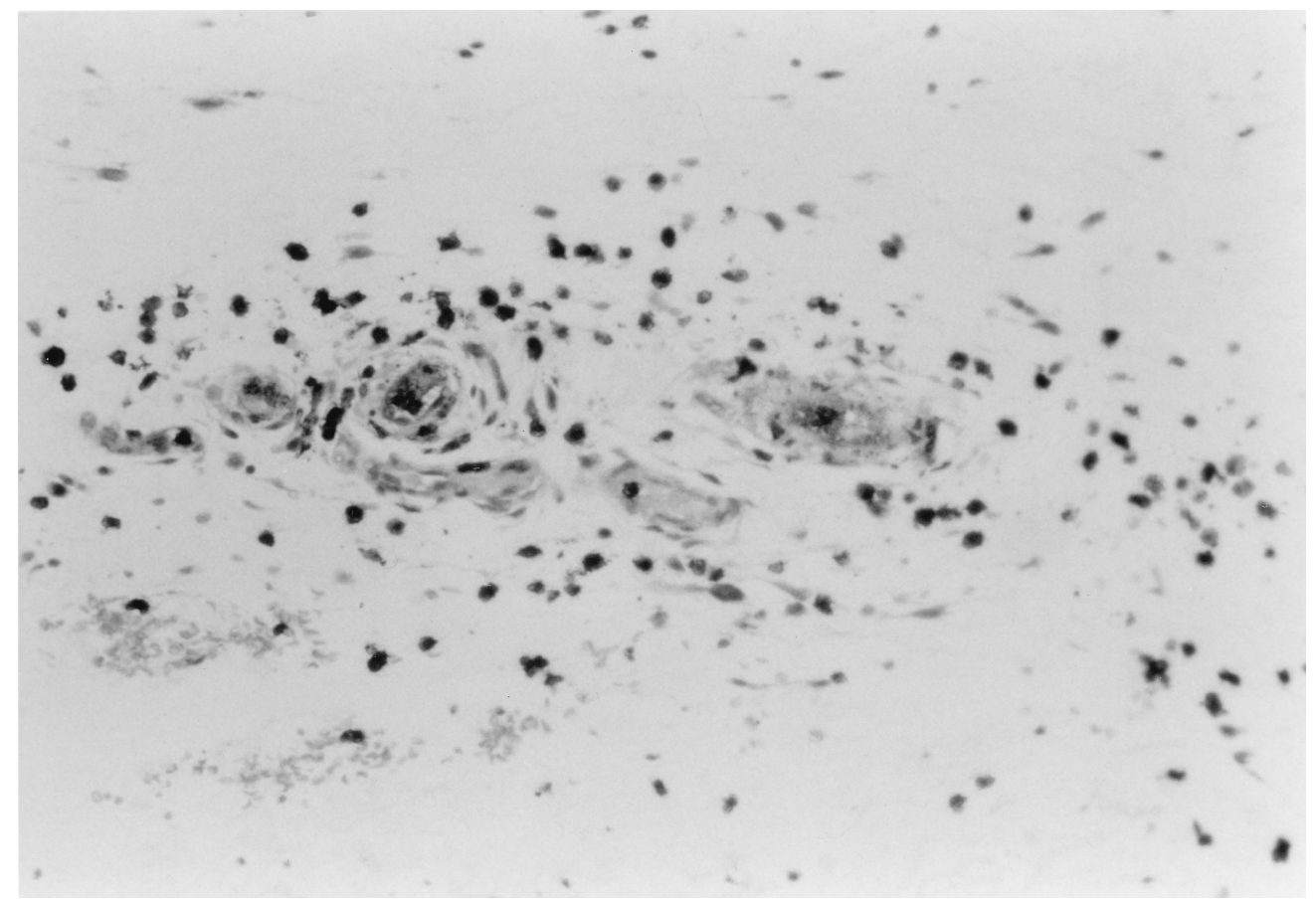

Fig. 5. Immunohistochemical stain for $\mathrm{CD} 43$ demonstrating a positive staining pattern in the lymphocytes infiltrating an infant homograft cardiac valve. (Original magnification $\times 320$.)

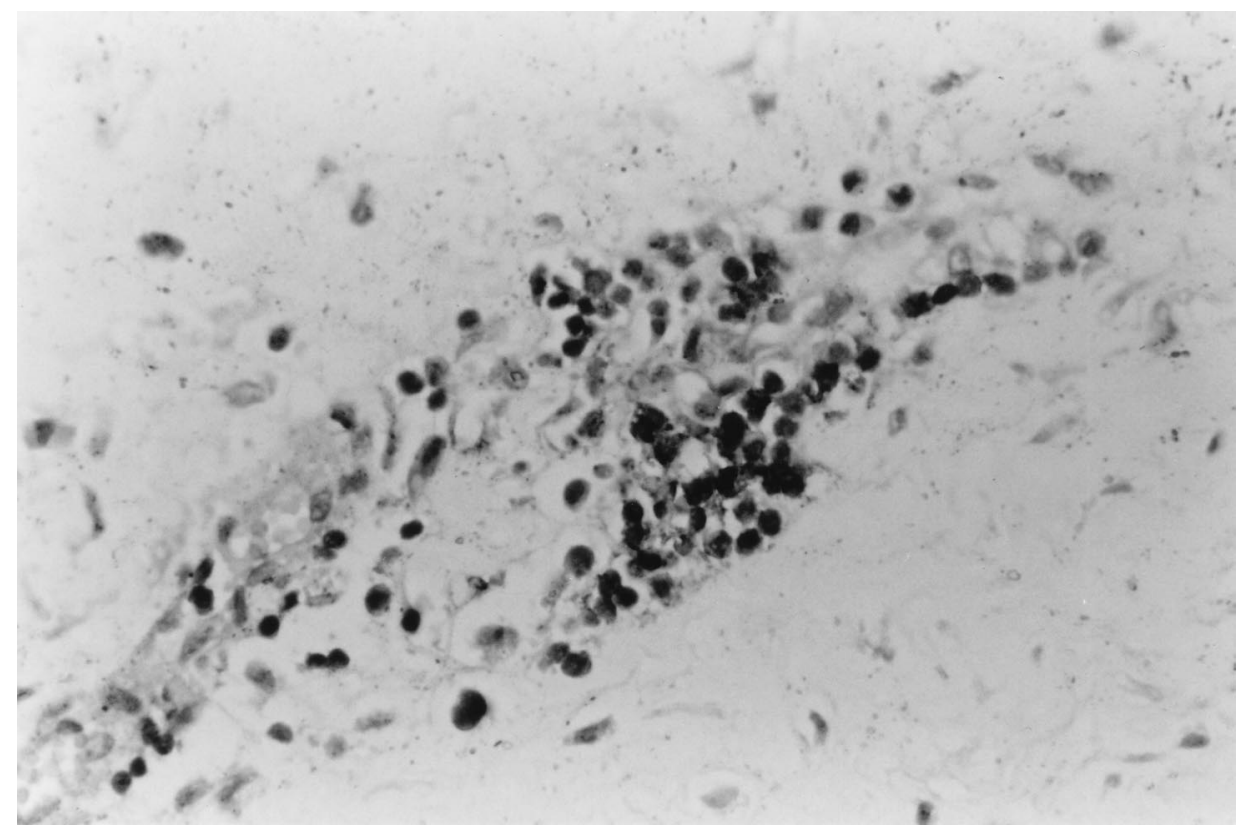

Fig. 6. Lymphocytic infiltrate in infant homograft valve demonstrating a positive staining pattern with CD20. (Original magnification $\times 650$.) 
eosinophils were found as part of the mononuclear cell infiltrate in one valve. Organizing mural thrombi were present in the homograft from the autopsy case. The Gomori methenamine silver and Gram stains for organisms were negative in all homograft valves. Other than the lymphocytic infiltrate, the media of the aortic sleeves, including the elastic lamellae, appeared unaltered. The adventitia of the aortic sleeves in the infant homograft valves was fibrotic, but no more so than would be expected in any postoperative state.

\section{Discussion}

In transplanted solid organs, including the heart, an infiltrate of $\mathrm{T}$ lymphocytes, coupled with altered structure and function, has been accepted as evidence of rejection. Rapid failure of the aortic homograft valve in these four infants, with a predominately T-cell lymphocytic infiltrate in the valve leaflets and aortic sleeves, is therefore consistent with rejection. That interpretation is buttressed by a recent report that donor-specific $\mathrm{T}$ lymphocytes can be cultured from explanted homografts. ${ }^{18}$ Treatment with cyclosporine (INN: ciclosporin) has been shown to arrest homograft degeneration in rat models, thus suggesting that such degeneration is caused by rejection. ${ }^{20}$ The hyperplastic intima (in all five valves) and thrombus formation (in the autopsy case) are similar to the findings seen in coronary arteries in transplant-associated vascular disease (accelerated atherosclerosis). ${ }^{21}$ Four of the five valves in the children failed as a result of insufficiency. The hyperplastic intima, as well as fibrosis of the leaflets and the sleeves, seems to have resulted in retraction of the leaflets. Why we found homograft valve rejection only in infants is not clear, but our findings are consistent with other reports of rapid failure of homografts in young children..$^{9,10}$ Other investigators have also observed aggregates of lymphocytes in homograft valves that were removed after a brief period of implantation, but they did not note the specific ages of the patients or the reasons for valve removal in these specific cases. ${ }^{22}$ Some authors suggest that homograft size may be a possible explanation for homograft failure in young recipients. ${ }^{9}$ Smaller homografts would be less susceptible to internal manipulation during dissection, which in turn would lead to less endothelial denuding than would take place in larger homografts. Graft endothelial cell membranes are positive for human leukocyte antigen (HLA) classes I and II, and maintaining cell viability, especially of endothelial cells, may promote rejection.
Another important factor in homograft valve rejection may be related to the method of pretransplantation preservation of those valves. Cryopreservation maintains cellular and tissue viability, ${ }^{14}$ which is thought to be key to the durability of cryopreserved homograft valves. ${ }^{23}$ However, maintaining cellular viability (especially endothelial cell viability) may result in an increased antigenic stimulus, as discussed earlier. All five homografts implanted in infants in our study had been cryopreserved, but the method of valve preservation is unknown for most of the adult homografts. Therefore it is difficult to make a comparison between the two groups with regard to method of preservation and time to valve failure.

Finally, as previously mentioned, cardiac valve homografts are usually transplanted without matching donor and recipient for blood group or HLA. This is in contrast to the protocol used for patients undergoing heart transplantation who, in addition, receive triple immunosuppression therapy. One study of 37 patients who died, on average (mean), 398 days after heart or heart-lung transplantation focused on the aortic valve. ${ }^{24}$ Optimal cusp viability and integrity were observed, even at long term, in these patients, suggesting that blood group or HLA matching and chronic immunosuppression may prevent early degeneration of the homograft valve.

The question of whether $\mathrm{ABO}$ compatibility affects the immunologic response has been debated on many occasions. No attempts to match the blood group of the recipient and donor were made for the five infant homograft valves in our study. In fact, the blood type of three of the five donors was never recorded.

In summary, in our series, all failed cardiac homograft valves in infants less than 1 year of age showed evidence of cellular rejection. All valves that demonstrated rejection had been cryopreserved. Cryopreserved homograft valves may not be immunoprivileged, and therefore consideration of measures to control rejection, such as blood group and HLA matching as well as immunosuppression, may be warranted.

\section{REFERENCES}

1. Ross DN. Homograft replacement of the aortic valve. Lancet 1962;2:487.

2. Gonzalez-Lavin L, Ross DN. Homograft aortic valve replacement: a five-year experience at the National Heart Hospital, London. J Thorac Cardiovasc Surg 1970;60:1-12.

3. Allwork SP, Pucci JJ, Cleland WP, Bentall HH. The longevity of sterilized aortic valve homografts, 1966-1972. J Thorac Cardiovasc Surg 1986;27:213-6. 
4. Angell WW, Angell JD, Oury JH, Lamberti JJ, Grehl TM. Long-term follow-up of viable frozen aortic homografts. J Thorac Cardiovasc Surg 1987;93:815-22.

5. Matsuki O, Robles A, Gibbs S, Bodnar E, Ross DN. Long term performance of 555 aortic homografts in the aortic position. Ann Thorac Surg 1988;46:187-91.

6. Angell WW, Oury JH, Lamberti JJ, Koziol J. Durability of the viable aortic allograft. J Thorac Cardiovasc Surg 1989;98: 48-56.

7. Kirklin JK, Smith D, Novick W, Naftel DC, Kirklin JW, Pacifico $\mathrm{AD}$, et al. Long-term function of cryopreserved aortic homografts. J Thorac Cardiovasc Surg 1993;106:154-64.

8. Yacoub M, Nasser RH, Rasmi RH, Sundt TM, Lund O, Boyland E, et al. Surgery for acquired heart disease: fourteen-year experience with homovital homografts for aortic valve replacement. J Thorac Cardiovasc Surg 1995;110:18694.

9. Clarke DR, Campbell DN, Hayward AR, Bishop DA. Degeneration of aortic valve allografts in young recipients. J Thorac Cardiovasc Surg 1993;105:934-42.

10. Yankah AC, Alexi-Meskhishvili V, Weng Y, Schorn K, Lange PE, Hetzer R. Accelerated degeneration of allografts in the first two years of life. Ann Thorac Surg 1995;60:571-7.

11. Thiede A, Timm C, Bernhard A, Müller-Ruchholtz W. Studies on the antigenicity of vital allogeneic valve leaflet transplants in immunogenetically controlled strain combinations. Transplantation 1978;26:391-5.

12. El Khatib H, Lupinetti FM. Antigenicity of fresh and cryopreserved rat valve allografts. Transplantation 1990;49:765-7.

13. Lupinetti FM, Christy JP, King DM, El Khatib H, Thompson SA. Immunogenicity, antigenicity and endothelial viability of aortic valves preserved at $4^{\circ} \mathrm{C}$ in a nutrient medium. Cardiac Surg 1991;6:454-61.

14. Fischlein T, Schütz A, Haushofer M, Frey R, Uhlig A, Detter $\mathrm{L}$, et al. Immunologic reaction and viability of cryopreserved homografts. Ann Thorac Surg 1995;60:S122-6.
15. Smith JD, Ogino H, Hunt D, Laylor RM, Rose ML, Yacoub MH. Humoral immune response to human aortic valve homografts. Ann Thorac Surg 1995;60:S127-30.

16. Hoekstra F, Knoop L, Aghai Z, Jutte N, Mochtar B, Bos E, et al. Stimulation of immune-competent cells in vitro by human cardiac valve-derived endothelial cells. Ann Thorac Surg 1995;60:S131-4.

17. Neves J, Monteiro L, Santos R, Martins A, Ramos S, Ramos $\mathrm{T}$, et al. Histologic and genetic assessment of explanted allograft valves. Ann Thorac Surg 1995;60:S141-5.

18. Hoekstra F, Knoop C, Vaessen L, Wassenaar C, Jutte N, Bos E, et al. Donor-specific cellular immune response against human cardiac valve allografts. J Thorac Cardiovasc Surg 1996;112:281-6.

19. Sheibani K, Tubbs RR. Enzyme histochemistry: technical aspects. Semin Diagn Pathol 1984;1:235-50.

20. Yankah AC, Wottge HU, Müller-Ruchholtz W. Short-course cyclosporin A therapy for definite allograft valve survival. Ann Thorac Surg 1995;60:S146-50.

21. Ratliff NB, Kottke-Marchant K. Pathology of atherosclerotic processes in cardiac allografts. In: Hauss WH, Wissler RW, Bauch HJ, editors. New pathogenic aspects of transplantation atheroarteritis. Seventh Münster International Arteriosclerosis Symposium. West Deutcher Verlas; 1994. p. 67-79.

22. Mitchell RN, Jonas RA, Schoen FJ. Structure function correlations in cryopreserved allograft valves. Ann Thorac Surg 1995;60:S108-13.

23. O'Brien MF, Stafford EG, Gardner MAH, Pohlner PG, McGiffin DC. A comparison of aortic valve replacement with viable cryopreserved and fresh allograft valves with a note on chromosomal studies. J Thorac Cardiovasc Surg 1987;94:81223.

24. Valente M, Faggian G, Billingham ME, Talenti E, Calabrese $\mathrm{F}$, Casula $\mathrm{R}$, et al. The aortic valve after heart transplantation. Ann Thorac Surg 1995;60:S135-40. 